\section{Visualizing Gene Expression in Real-Time}

\author{
Stephen W. Carmichael ${ }^{1}$ \\ Mayo Clinic \\ stephen.carmichael@mayo.edu
}

Gene expression has been visualized for a few decades, but in static forms such as blots and gene chips. Susan Janicki, Toshiro Tsukamoto, Simone Salghetti, William Tansey, Ravi Sachidanandam, Kannanganattu Prasanth, Thomas Ried, Yaron Shav-Tal, Edouard Bertrand, Robert Singer, and David Spector have recently designed a cell line in which gene expression can be observed with stunningly accurate spatial and temporal resolution. $^{2}$ Gene expression is a cascade of events beginning with transcription of RNA from the DNA template and ending with translation into a protein sequence. Janicki et al. were able to visualize the entire process at the levels of DNA, RNA, and proteins in living cells!

As pointed out by the authors, several specific steps in the gene expression paradigm have been discovered and extensively studied in vitro. However, the dynamics of mRNA synthesis at a single specific transcription site has not been revealed. They developed a cell line that allows the investigation of how events of gene expression are coordinated spatially and temporally in vivo. They began by constructing a plasmid, containing a transcription unit, and stably integrating it into a human cancer cell line. With the addition of other plasmids, they had a cell line that produced a series of detectable markers at specific events during gene expression. Transfected cells were maintained in a physiologic chamber on an inverted microscope and time-lapse imaging was acquired. Stacks of several images $0.5 \mu \mathrm{m}$ apart were taken to assure that at least one image was focused on the structure of interest for each time point. Different wavelengths were used to excite the different reporter fluorochromes.

After extensive analysis, the interconnectedness of chromatin remodeling, transcription, mRNA processing, and messenger ribonucleoprotein (mRNP) export became apparent. Janicki et al. developed a cell system that allows the visualization of an inducible array of transcription units and their RNA and protein products in living cells. This allows the evaluation of dynamic changes in chromatin structure, RNA synthesis, and factor dissociation/association during the induction of transcription. The movie can be seen at http://spectorlab.cshl.edu. This study provided significant insight into the dynamic spatial and temporal changes that occur as chromatin transitions from a heterochromatic to a euchromatic state. This system has considerable potential to address a broad range of questions relating to gene expression, DNA replication, and chromatin stability!

\section{References}

1. The author gratefully acknowledges Dr. David Spector for reviewing this article.

2. Janicki, S.M., T. Tsukamoto, S.E. Salghetti, W.P. Tansey, R. Sachidanandam, K.V. Prasanth, T. Ried, Y. Sharon Shav-Tal, E. Bertrand, R.H. Singer, and D.L. Spector, From silencing to gene expression: Real-time analysis in single genes, Cell 116:683-698, 2004.

\title{
InPEX Of ARTIOIES
}

Visualizing Gene Expression in Real-Time

Stephen W. Carmichael, Mayo Clinic

"Objects Worthy of Notice" Microscopical Anatomy of

Selected Plants Collected by The Lewis \& Clark Expedition .....8

Harry A. Alden and Roland H. Cunningham, Smithsonian Center for

Materials Research and Education; Kevin Ryan and Paul T. Jantzen

Media Cybernetics, Inc.; and David R. Dobbins, Millersville University

A Novel GEMINI ${ }^{\circledR}$ STEM Detector System ... 18

Jack Vermeulen and Heiner Jaksch, Carl Zeiss SMT, Germany

Phase Measurement in Electron Microscopy

Using the Transport of Intensity Equation .22

Kazuo Ishizuka, HREM Research Inc. and Brendan Alman, IATIA Ltd.

High Resolution Light Microscopy of Live Cells .26

Vitaly Vodyanoy, Auburn University

Nondestructive, High-Resolution Materials Characterization with the Confocal Raman-AFM ...30

U. Schmidt, A. Jauss, W. Ibach, K. Weishaupt, and O. Hollricher

WITec GmbH. Ulm, Germany

Making Anaglyphs in Photoshop

Jerry Sedgewick, University of Minnesota

Ultra High Resolution SEM on Insulators and

Contaminating Samples

Trisha Rice, Hillsboro, $O R$ and Ralph Knowles FEI Eindhoven, The Netherlands

Influence of Illumination Conditions on Temperature in Sample Cell and the Output of a Quadrant Detector in an Optical

Tweezers System

Yuqiang Jiang, ${ }^{1,2,3}$ H. Guo, ${ }^{2}$ C. Liu, ${ }^{2}$ Z. Li,2 B. Cheng, ${ }^{2}$ D. Zhang, ${ }^{2}$

and S. Jia; ${ }^{1}$ Shanxi University, Taiyuan, P. R. China

${ }^{2}$ Chinese Academy of Science, Beijing, P. R. China

${ }^{3}$ Shanxi Datong University, Datong, P. R. China
3 Microwave Protocols for Plant and Animal

Paraffin Microtechnique 50

Denise Schichnes, Jeffrey A. Nemson, and Steven E. Ruzin,

The University of California at Berkeley

Raman Microscopy as an Aid in Failure Analysis -

Examples From the Lab

W. John Wolfgong, Raytheon, McKinney, TX

Virtual Electron Microscopy for

Undergraduate/Graduate Classes

Elaine Humphrey, University of British Columbia, Canada

New and Interesting PITTCON 2005 ............................60 60

Industry News ......................................................... 61

NetNotes....................................................................... 64

Index of Advertisers.......................................................... 70

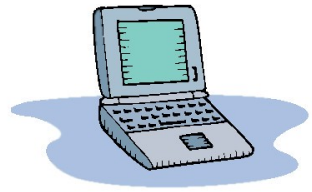

ABOUT THE OOVER

Lewis and Clark in Camp on Traveler's Rest,

(Lolo) Creek, Montana

September 10, 1805

by Edgar Paxson

This watercolor $(1903,5-1 / 2$ " by 7 "), the frontispiece for Volume 1 of Wheeler's /The Trail of Lewis and Clark/ (1904), became the prototype for one of the murals Paxson painted for the Missoula County Courthouse in 1914. From Discovering Lewis \& Clark $^{\star}$, http://www.lewis-clark.org (C) 1998 VIAs Inc. See the article by Alden, et al. on page 8 . 


\section{4th Anniversary S219 4th Anniversary The Detector That Revolutionized EDS}

\section{High performance EDS without liquid nitrogen}

- Convenience - especially for multi-user environment

- Cool only when needed - 20 second cooldown

- No tending detector during vacation or plant closings

- No liquid nitrogen related safety hazards

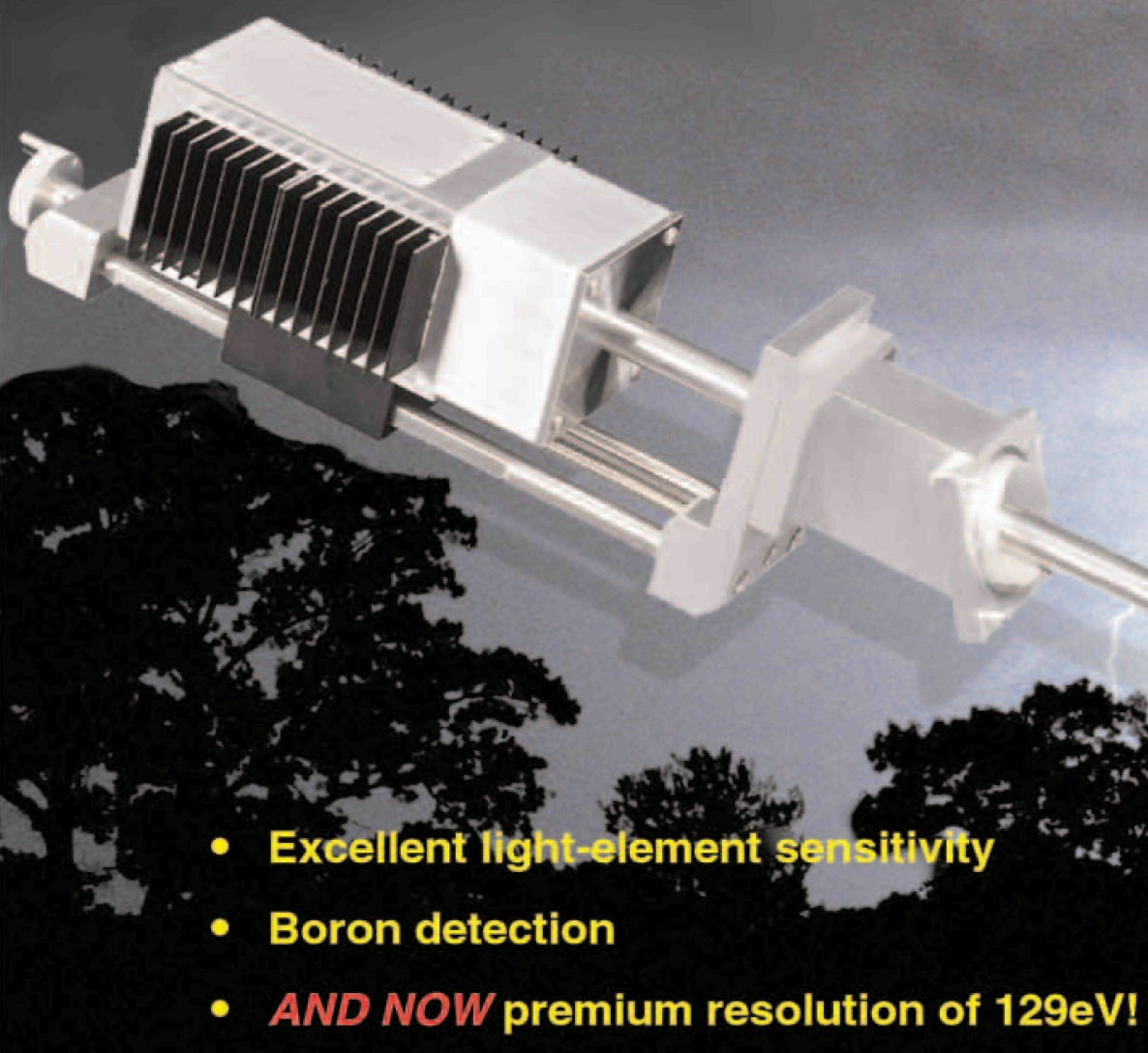

Sahara - proven quality \& performance

For more information visit our web site: www.pgt.com/sahara.html

Princeton Gamma-Tech, Inc. 1026 Route 518

Rocky Hill, NJ 08553

Web site: www.pgt.com
Tel: (609) $924-7310$

Fax: (609) 924-1729

Toll free: $800-229-7484$

e-mail: sales@pgt.com

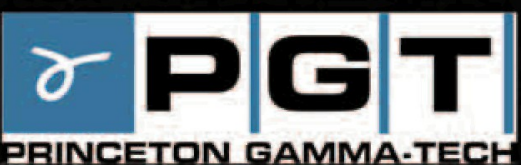




\section{Let Buehler Complete Your Circuit}

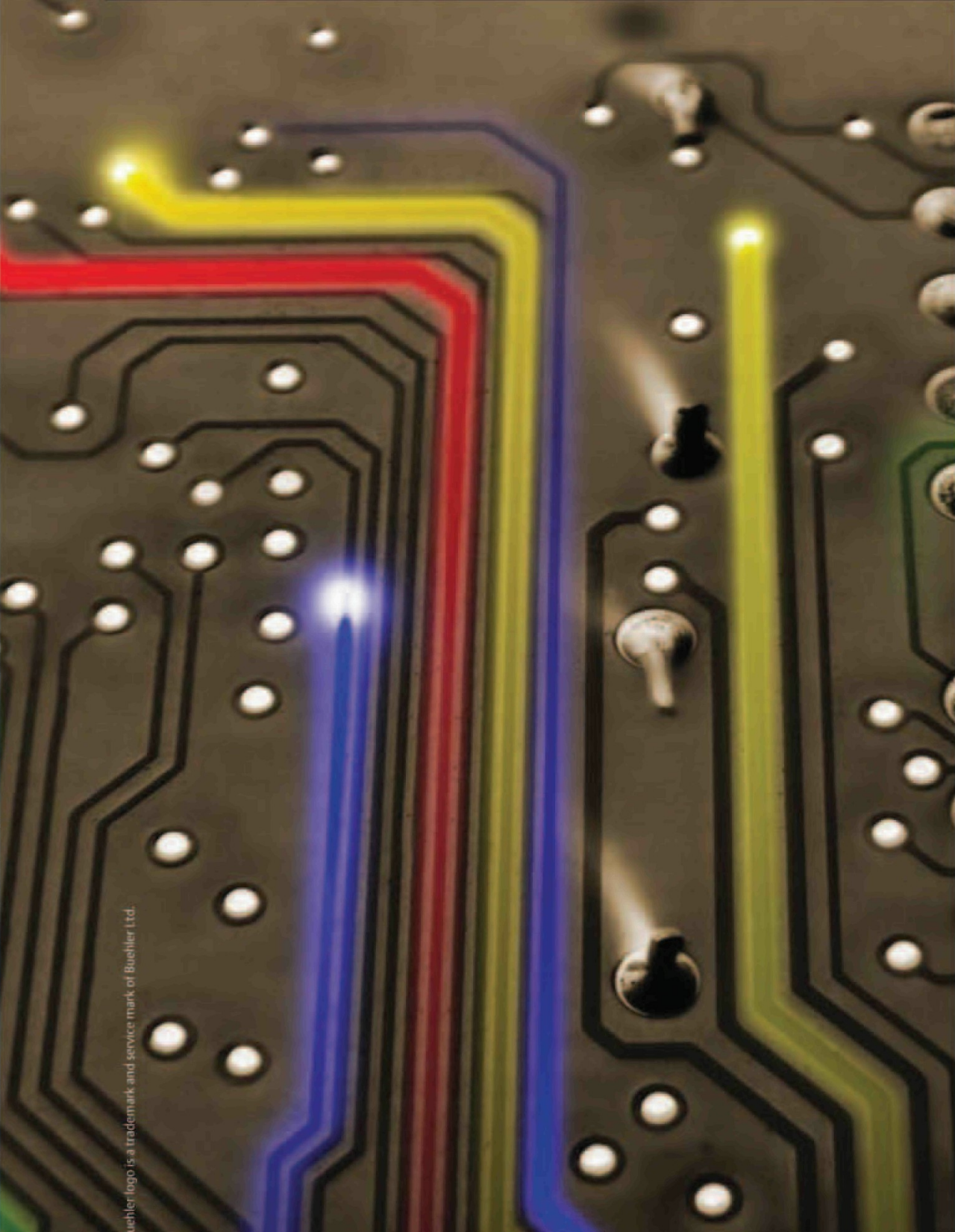

The importance of testing Printed Wiring Boards (PWBs) continues to increase as new electronic equipment enters the market, with increased function, new packaging and greater performance. Each step of the manufacturing process is critical, especially with smaller through-holes. Buehler is ready to meet your $R \& D$, testing and failure analysis needs with our new PWB Met Family of high precision through-hole cross-sectioning equipment.

\section{Flexibility}

A standard coupon sample can be removed anywhere on the PWB with Buehler's PWB Met Router. This is particularly useful for multilayer boards which are too thick for removal without inducing damage from a punch and die or when they cannot be removed on the production line. Routing ensures specimens that truly represent the manufacturing process.

\section{High Volume with Increased Accuracy}

Accurately pinpoint through-holes you wish to target for examination on the PWB Met Digital Alignment Drill. The onscreen alignment system allows your operator to easily align target holes, and automatically position drilling holes for the precision mounting pins. The PWB Met Small Hole Accessory cross-sections up to 18 coupons or 36 holes to target depth, quickly and effectively, thus providing enhanced productivity and cross-sectional accuracy for microvia holes as small as 4 mil $(100 \mu \mathrm{m})$.

\section{Meeting your Needs}

Whether cross-sectioning through-holes or preparing integrated circuits and discrete components, we have the complete solution for your electronics preparation. Buehler is your best connection.

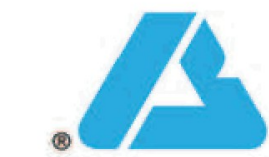

\section{BUEHLER}

Worldwide Headquarters

Buehler Ltd * 41 Waukegan Road * Lake Bluff, Illinois 60044 - USA Tel: (847) 295-6500 • Fax: (847) 295-7979

Email: info@buehler.com - Web Site: http://www.buehler.com (An Emerson Industrial Automation subsidiary since 1992)

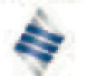

EMERSON

Industrial Automation 


\section{ooming avents}

\section{5}

$\checkmark$ EM 2005-12th Intl. Conf. on Electron Microsc. of Solids June 5-9, 2005, Kazimierz Dolny, Poland katcki@ite.waw.pl

$\checkmark$ Lehigh Microscopy School June 5-17, 2005, Lehigh University, Bethlehem, PA www.lehigh.edu/microscopy

$\checkmark$ Fourth International Cryo EM course June 7 - 16, 2005, Univ, of British Columbia, Vancouver, Canada ech@interchange.ubc.ca

$\checkmark$ Inter/Micro - 2005

July $11-15,2005$, Chicago, Illinois www.mcri.org/IM_info_page.html

$\checkmark$ Cryo-HRSEM/STEM/TEM Short Course July 13-15, 2005, Emory Univ. Atlanta, GA electronmicroscopy.emory.edu

$\checkmark$ AFM and Other Scanned Probe Microscopies June $13-17,2005$, N.C. State University in Raleigh, NC www.ncsu.edu/aif/afmcourse

$\checkmark$ 6th International Weber Symposium on Innovative Fluorescence Methodologies in Biochemistry and Medicine July 22-28, 2005, Kauai, Hawaii http://lfd.uiuc.edu/weber/

$\checkmark$ Microscopy and Microanalysis 2005 July 31 - August 4, 2005, Honolulu, HA www.msa.microscopy.com

$\checkmark$ 12th Canadian Semiconductor Technology Conference August $16-19,2005$, Ottawa, Ontario, Canada http://www.canadiansemiconductor.org

$\checkmark$ Scanning Probe Microscopy in Life Sciences October 13, 2005, Berlin, Germany www.spm-workshop.jpk.com

\section{$\checkmark$ Society for Neuroscience}

November 12-16, 2005, Washington, DC info@sfn.org

$\checkmark$ Materials Research Society esp: In-Situ Electron Microscopy of Materials, Symposium MM November 28- December 2, 2005, Boston, MA info@mrs.org

$\checkmark$ 9th International Symposium on Biomineralization December 6-9, 2005. Pucón, Chile www.cimat.cl/biomin09

$\checkmark$ American Society for Cell Biology 2004 December 10-14, 2005, San Francisco, CA www.ascb.org

2006

$\checkmark$ Microscopy and Microanalysis 2006 August 6-10, 2006, Chicago, IL www.msa.microscopy.com

2007

$\checkmark$ Microscopy and Microanalysis 2007 August 5-9, 2007, Fort Laurderdale, FL www.msa.microscopy.com

2008

$\checkmark$ Microscopy and Microanalysis 2008 August 3-7, 2008, Albuquerque, NM www.msa.microscopy.com

Please check the "Calendar of Meetings and Courses" in the MSA journal "Microscopy and Microanalysis" for more details and a much larger listing of meetings and courses.

\section{IIOROsoopY TOPiY}

The objective of this publication is to provide material of interest and value to working microscopists!

The publication is owned by the Microscopy Society of America (MSA) and is produced six times each year in odd months, alternating with MSA's peer-reviewed, scientific journal Microscopy and Microanalysis. We greatly appreciate article and material contributions from our readers- "users" as well as manufacturers/suppliers. The only criterion is that the subject matter be of interest to a reasonable number of working microscopists. Microscopy Today has authors from many disparate fields in both biological and materials sciences, each field with it's own standards. Therefore $M T$ does not have a rigid set of style instructions and encourages authors to use their own style, asking only that the writing be clear, informative, and accurate. Length: typical article length is 1,500 to 2,000 words plus images, longer articles will be considered. Short notes are encouraged for our Microscopy 101 section.

\section{mICROSCOPY TODAY}

\author{
ISSN 1551-9295
}

Ron Anderson, Editor

randerson20@tampabay.rr.com

José Mascorro, Technical Editor

jmascor@tulane.edu

Thomas E. Phillips, Contributing Editor

PhillipsT@missouri.edu

Dale Anderson, Art Director

microscopytoday@tampabay.rr.com

Regular Mail to:

Microscopy Today, P.O. Box 247, Largo, FL 33779

Courier Mail to:

1001 Starkey Road, Lot \#374, Largo, FL 33771

Telephones:

1-(727)507-7101 • Fax: (727)507-7102 • Cell: (727) 631-1022 e-Mail:

microscopytoday@tampabay.rr.com www Page:

http://www.microscopy-today.com

Total Circulation: 14,388

Disclaimer: By submitting a manuscript to Microscopy Today, the author warrants that the article is original (or that the author has the right to use any material copyrighted by others). The use of trade names, trademarks, etc., does not imply that these names lack protection by relevant laws and regulations. Microscopy Today, the Microscopy Society of America, and any other societies stated, cannot be held responsible for opinions, errors, or for any consequences arising from the use of information contained in Microscopy Today. The appearance of advertising in Microscopy Today does not constitute an endorsement or approval by the Microscopy Society of America of the quality or value of the products advertised or any of the claims, data, conclusions, recommendations, procedures, results or any information found in the advertisements. While the contents of this magazine are believed to be accurate at press time, neither the Microscopy Society of America, the editors, nor the authors can accept legal responsibility for errors or omissions.

c) Copyright, 2005, The Microscopy Society of America. All rights reserved. 


\section{CrossBeam ${ }^{\oplus}$ EsB - FIB Workstation with Ultra High Resolution Imaging at Low kV}

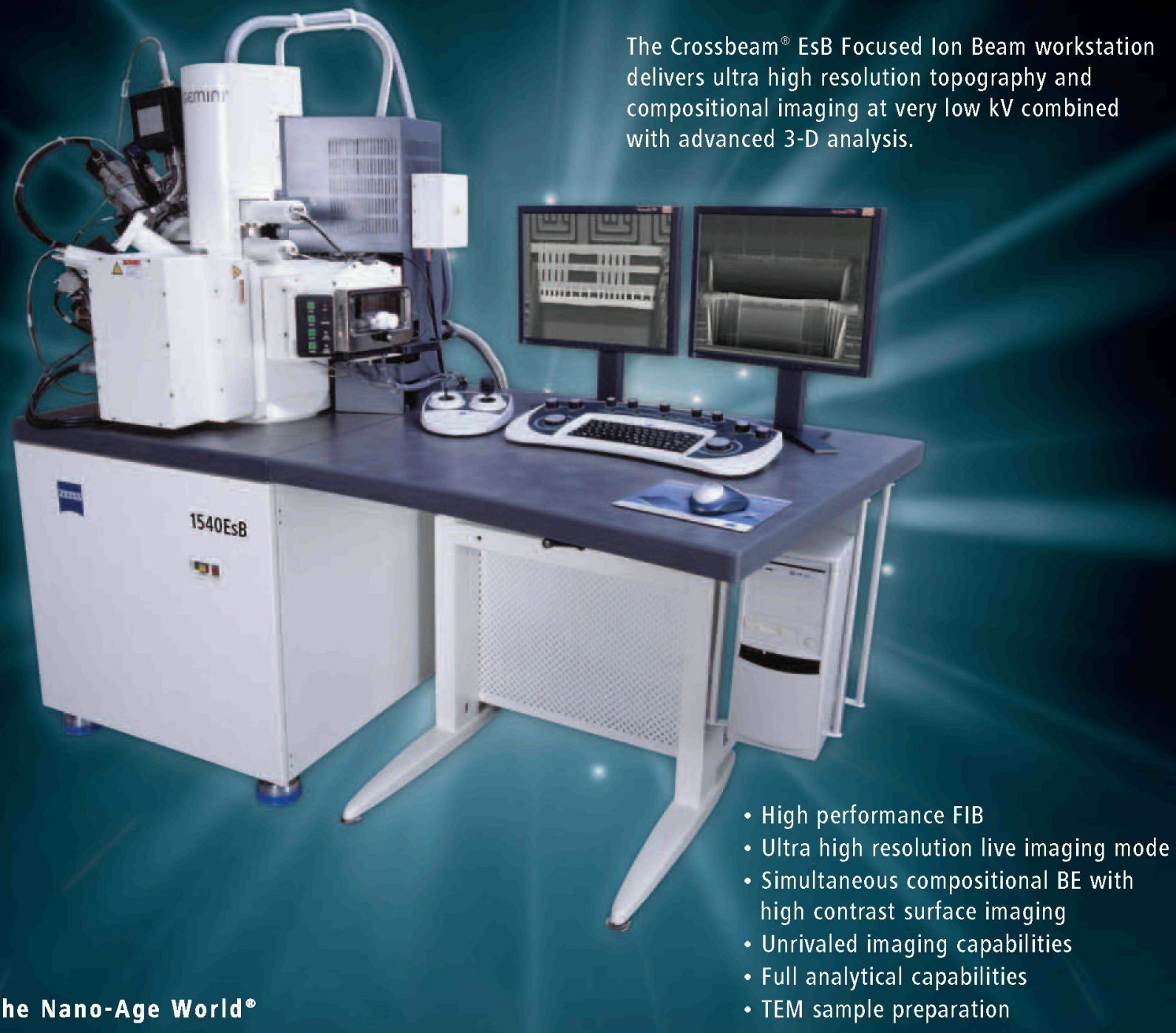

Enabling the Nano-Age World

The Crossbeam ${ }^{\oplus}$ EsB Focused Ion Beam workstation delivers ultra high resolution topography and compositional imaging at very low $\mathrm{kV}$ combined with advanced 3-D analysis.

- Ultra high resolution live imaging mode

- Simultaneous compositional BE with high contrast surface imaging

- Unrivaled imaging capabilities

TEM sample preparation

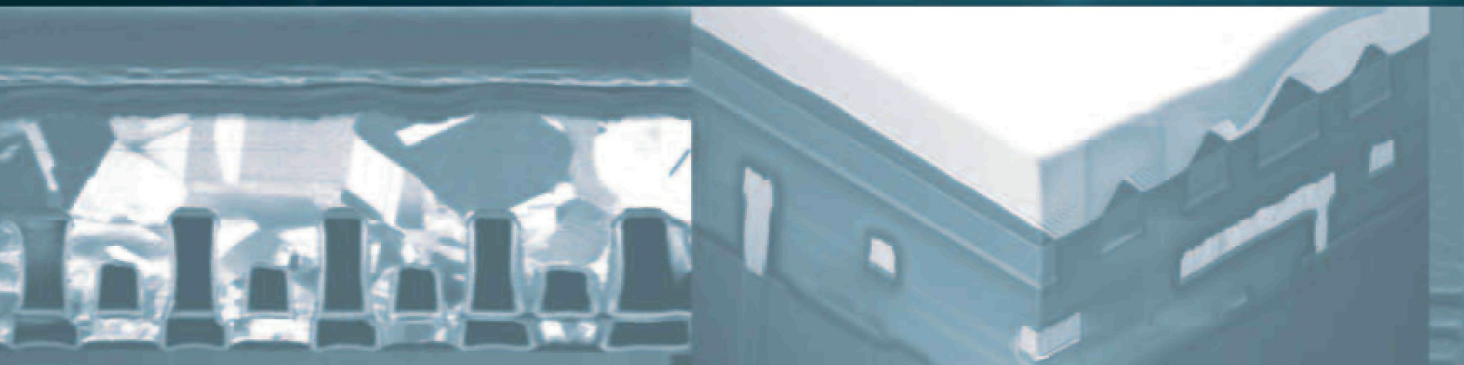

Nano Technology Systems Division One Zeiss Drive

Thornwood, New York 10594 USA
Tel. $+1914 / 7477700$

Fax $+1914 / 6817443$

info-usa@smt.zeiss.com

www.smt.zeiss.com/nts 